\title{
Characterizations and X-ray Crystal Structure of Asymmetrical 2,4,9,11-Tetramethyl- 1,5,8,12-monobenzotetraazacyclo[14]annulene Palladium(II) Complex
}

\author{
D. I. Kim, Z. U. Bae, H. G. Na, J. C. Byun $\stackrel{\ddagger}{*}$ J. H. Choi, ${ }^{, * *}$ and Y. C. Park ${ }^{*}$ \\ Department of Chemistr, Kumgpook National Iniversin; Daegu 702-701. Korea \\ -Department of Chemistry. Daejin Lniversitw. Pochon $487-800$, Korea \\ -Department of Chemistr. Cheju National Universin, Cheju 690-756. Korea

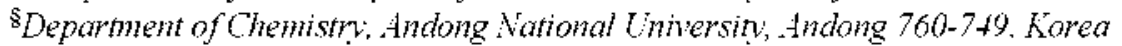 \\ Received November 18,2003
}

Key Words : Free ligand. Molecular stnıcture. Palladium(II) complex

It is reported that symmetrical dibenzotetraazacyclo[14]annulene are generally complexed with a variety of metals such as nickel copper and cobalt. ${ }^{l-7}$ The studies of the metal complexes of tetraazaannulene. which have been well known to possess chemical and thermal stability have been of considerable attention because of their utilities as electrocatalysts or model compounds in biological system. ${ }^{8-14}$ Tetraazaamulenes as ligands prefer to coordinate with a metal ion in a square-planar fashion like porphỵrines or phthalocyanines. Especially palladium coordination complexes with macrocycle ligands such as tetraazaannulene or porphỵrin typically prefer a square-planar arrangement as the most stable stnucture and are very resistive to chemical demetallation due to the stability of its square-planarity: ${ }^{15-17}$ The first X-ray structure of stmmetrical tetraaza[14]annulene palladium(II) complex is reported by Tsutsui. M. et al in 1979 . $^{\text {Is }}$ The complexes reported in asymmetrical monobenzotetraaza[14]annulene are mostly to include nickel(II) ion. 19.3 On the other hand. the palladium complex has scarcely been reported because it is not easy to prepare an asymmetrical free-based ligand in comparison to symmetrical free-based ligand. Herein. we synthesized and characterized a free-based asymmetrical 2.4.9.11-tetramethyl-1.5.8.12monobenzotetraazacyclo[14]annulene (L) and its palladium complex $([\mathbf{P d L}])$ and determined the structure of the $[\mathbf{P d L}]$ by X-ray diffraction study:

\section{Experimental Section}

Materials. $\mathrm{Ni}(\mathrm{OAc})_{2}+4 \mathrm{H}_{2} \mathrm{O}$. 1.2-pheny lenediamine. 1.2diaminoethane. $\mathrm{Pd}(\mathrm{OAc})_{2}$. $\mathrm{NaCN}$ and 2.4-pentandione were purchased from Aldrich and Fluka. The solvents such as $\mathrm{CH}_{3} \mathrm{CN} . \mathrm{CH}_{3} \mathrm{OH} . \mathrm{CH}_{3} \mathrm{CH}_{2} \mathrm{OH}, \mathrm{CH}_{2} \mathrm{Cl}_{2}$ were refluxed over calcium hydride under nitrogen. and checked for purities by GC just before use. Dimethylsulfoxide (DMSO) was purchased from Merck and used without further more purification. Tetraethylammonium perchlorate (TEAP) used as supporting electrolyte was prepared and purified by the method described by Kolthoff and Coetzee. ${ }^{2 l}$

\footnotetext{
"Co-Corresponding Authors: Y. C. Park (ychparkiâ' knu.ac.kr); I. H. Choi (jhehoi ta andong.ac.kr)
}

Measurements. Elemental analyses $(\mathrm{C} . \mathrm{H}, \mathrm{N})$ of the compounds prepared were carried out on a Carlo-Ebra. EA 1108 instrument. Infrared spectra were recorded on a Matteson Instruments. Inc. Galaxy 7020 A using KBr Pellets. ${ }^{1} \mathrm{H}-\mathrm{NMR}(300 \mathrm{MHz}$ ) spectra were recorded on a Brucker instrument at room temperature and chemical shifts in $\mathrm{CDCl}_{3}$ were given in ppn relative to tetramethylsilane as internal reference. Electronic absorption spectra were obtained on a Shimadzu UV-265 spectrophotometer.

Cyclic voltammetry was performed using a Bioanalytical System (BAS) CV-50W electrochemical analyzer and C2 cell stand at room temperature. The three electrodes system for the electrochenical measurements composed of the glassy carbon electrode as a working electrode, and $\mathrm{Ag} / \mathrm{Ag}^{-}$ (0.01 $\mathrm{M} \mathrm{AgNO}_{3}$ in $0.1 \mathrm{M}$ TEAP DMSO solution) as a reference electrode. and a platinum wire as an auxiliary electrode was used

Synthesis: 2,4,9,11-Tetramethyl-1,5,8,12-monobenzotetraazacyclol 1 Hanmulene $(\mathrm{L})$. This ligand was prepared by modifying L'Eplattenier and Pugin's method '2 At first the asymmetrical 2.4.9.11-tetramethyl-1.5,8.12-monobenzotetraaza-cyclo[14]annulene nickel(II) as starting compound was prepared by the method reported in the literature. ${ }^{23.24}$ The complex $(5.28 \mathrm{~g} .0 .015 \mathrm{~mol}$ ) was dissolved in absolute ethanol $(50 \mathrm{~mL})$ and was treated excess anhydrous hydrocluloric acid until the blue colored ligand salt precipitate. The reaction mixture was further stirred at room temperature for $18 \mathrm{~h}$. The solid was filtered. dissolved in water $(300 \mathrm{~mL})$ and neutralized by addition of solid sodium cyanide. The yellow precipitate was recovered washed with water dried in vacuo. The red single crystal could be obtained by recrystallizing from a mixture (1: 1$)$ of dichloromethane and methyl alcohol. Yield $1.11 \mathrm{~g}(25 \%)$. Anal. Calcd for $\mathrm{C}_{18} \mathrm{H}_{24} \mathrm{~N}_{4}: \mathrm{C}$. 72.94: H, 8.16: N. 18.90\%: Found: C, 72.78: H, 8.22: N. $18.93 \%$. IR $\left(\mathrm{KBr}\right.$ disc. $\left.\mathrm{cm}^{-1}\right): v(\mathrm{C}=\mathrm{C}) .1502: v(\mathrm{C}=\mathrm{N}), 1562$ : $v\left(\mathrm{C}_{6} \mathrm{H}_{6}\right), 746$. UV-vis: $\lambda_{m a x}(\mathrm{~nm})$ and $\varepsilon_{m a x}\left(\mathrm{M}^{-1} \mathrm{~cm}^{-1}\right)$ in $\mathrm{CHCl}_{3} 322$ and $36000 .{ }^{1} \mathrm{H}$ NMR (CDCl 3$): 1.972 .2 .101$ (s) (methyl): $4.757(\mathrm{~s})$ (methine): 3.443(s) (ethylene): 6.945 (n) (aromatic): 11.873 (br) (N-H).

2, + 9,11-Tetramethy 1, 5,8,12-monobenzotetraazacyclo[14]annilene palladitm(Il) $([\mathrm{PdL}]) . \mathrm{Pd}(\mathrm{OAc})_{2}(0.224 \mathrm{~g} .0 .001$ $\mathrm{mol}$ ) and free based ligand (L: $0.296 \mathrm{~g} .0 .001 \mathrm{~mol})$ was 
dissolved in acetonitrile $(80 \mathrm{~mL})$. The mixture was heated under reflux for $2 \mathrm{~h}$ with stirring and bubbled nitrogen gas for protecting from moisture. The reaction mixture was left to stand in refrigerator for $12 \mathrm{~h}$. The solid was filtered and washed with acetonitrile. The product was chromatographed on aluminum oxide and eluted with chloroform. The yellow effluent was collected. evaporated to dryness in victo and dried. The dark brown crystal was obtained by recrystallizing from a mixture of dichloromethane and methyl alcohol $(1: 1)$. When the powder was yellow color but the crystal was dark brown. Yield $0.159 \mathrm{~g}(40 \%)$. Anal. Calcd. for $\mathrm{C}_{18} \mathrm{H}_{2 \mathrm{i}} \mathrm{PdN}_{4}: \mathrm{C}, 54.17 ; \mathrm{H}, 5.02: \mathrm{N}$. 14.11\%; Found: C. 53.79: H. 5.64: $\mathrm{N}, 14.11 \%$. IR $\left(\mathrm{KBr}\right.$ disc. $\left.\mathrm{cm}^{-1}\right): v(\mathrm{C}=\mathrm{C}), 1514$ : $v(\mathrm{C}=\mathrm{N}), 1569 ; v\left(\mathrm{C}_{6} \mathrm{H}_{6}\right) .744$. UV-vis: $\lambda_{\text {mix }}(\mathrm{nm})$ and $\varepsilon_{\text {max }}$ $\left(\mathrm{M}^{-1} \mathrm{~cm}^{-1}\right)$ in $\mathrm{CHCl}_{3} 374$ and 19000,432 and $11000 .{ }^{1} \mathrm{H}$ NMR ( $\left.\mathrm{CDCl}_{3}\right): 2.187 .2 .569$ (s) (methyl): 4.998 (s) (methine): 3.773 (s) (ethylene): 6.820-7.514 (m) (aromatic).

$\mathrm{X}$-ray crystallographic analysis: Preliminary examination and data collection for crystal of palladium(II) complex were performed with Mo-K $\alpha$ radiation $(\lambda=0.71073 \AA)$ on an Euraf-Nonius CAD4 computer controlled $k$-axis diffracto-

Table 1. Crystal data and structure refinement for palladiun(II) complex ([PdL])

\begin{tabular}{|c|c|}
\hline Empirical formula & $\mathrm{C} 18 \mathrm{H} 20 \mathrm{~N} 4 \mathrm{Pd}$ \\
\hline Formula weight & 398.78 \\
\hline Temperature & $173(2) \mathrm{K}$ \\
\hline Wavelength & $0.71073 \AA$ \\
\hline Crystal system & Orthorhombic \\
\hline Space group & $\mathrm{P} 2,2,2$, \\
\hline Unit cell dimensions & $\begin{array}{l}a=8.1003(12) \AA \alpha=90^{\circ} . \\
b=8.2553(13) \AA \beta=90^{\circ} . \\
c=24.416(4) \AA \gamma=90^{\circ} .\end{array}$ \\
\hline Volume & $1632.7(4) \AA^{3}$ \\
\hline Z & 4 \\
\hline Density (calculated) & $1.622 \mathrm{Mg} / \mathrm{m}^{3}$ \\
\hline Absorption coefficient & $1.141 \mathrm{mmm}^{-1}$ \\
\hline $\mathrm{F}(000)$ & 808 \\
\hline Crystal size & $0.38 \times 0.28 \times 0.25 \mathrm{mmm}^{2}$ \\
\hline Theta range for data collection & 1.67 to $28.32^{\circ}$ \\
\hline Index ranges & $\begin{array}{l}-10<=h<=10 \\
-10<=k<=10 \\
-32<=1<=23\end{array}$ \\
\hline Reflections collected & 9553 \\
\hline Independent reflections & $3837[\mathrm{R}($ int $)=0.0283]$ \\
\hline Completeness to theta $=28.32^{\circ}$ & $96.3 \%$ \\
\hline Absorption correction & $\begin{array}{l}\text { Semi-empirical from } \\
\text { equivalents }\end{array}$ \\
\hline Max and min. transmission & 0.7635 and 0.6710 \\
\hline Retinement method & Full-matrix least-squares on $F^{*}$ \\
\hline Data / restraints / parameters & $3837 / 0 / 212$ \\
\hline Goodness-of-tit on $\mathrm{F}^{2}$ & 1.096 \\
\hline Final R indices $[\mathrm{I}>2 \operatorname{sigma}(\mathrm{I})]$ & $\mathrm{RI}=0.02 \mathrm{I} 8, \mathrm{wR} 2=0.0571$ \\
\hline $\mathrm{R}$ indices (all data) & $\mathrm{R} 1=0.0228, \mathrm{wR} 2=0.0576$ \\
\hline Absolute structure parameter & $0.03(3)$ \\
\hline Largest dift. peak and hole & 0.583 and $-0.755 \mathrm{e} A^{-3}$ \\
\hline
\end{tabular}

Table 2. Selected bond distances $[\AA]$ and angles $\left[{ }^{\circ}\right]$ for palladium (II) complex ([PdL])

\begin{tabular}{llll}
\hline $\mathrm{Pd}-\mathrm{N}(1)$ & $1.977(2)$ & $\mathrm{P} d-\mathrm{N}(2)$ & $1.978(2)$ \\
$\mathrm{Pd}-\mathrm{N}(3)$ & $1.966(2)$ & $\mathrm{Pd}-\mathrm{N}(4)$ & $1.957(2)$ \\
$\mathrm{N}(1)-\mathrm{C}(1)$ & $1.4(69(3)$ & $\mathrm{N}(1)-\mathrm{C}(16)$ & $1.343(3)$ \\
$\mathrm{N}(2)-\mathrm{C}(2)$ & $1.41(3)$ & $\mathrm{N}(2)-\mathrm{C}(7)$ & $1.341(3)$ \\
$\mathrm{N}(3)-\mathrm{C}(9)$ & $1.3(77(3)$ & $\mathrm{N}(3)-\mathrm{C}(12)$ & $1.461(4)$ \\
$\mathrm{N}(4)-\mathrm{C}(13)$ & $1.452(4)$ & $\mathrm{N}(4)-\mathrm{C}(14)$ & $1.391(4)$ \\
$\mathrm{C}(1)-\mathrm{C}(2)$ & $1.441(3)$ & $\mathrm{C}(1)-\mathrm{C}(6)$ & $1.393(3)$ \\
$\mathrm{C}(7)-\mathrm{C}(8)$ & $1.393(4)$ & $\mathrm{C}(7)-\mathrm{C}(10)$ & $1.517(3)$ \\
$\mathrm{C}(8)-\mathrm{C}(9)$ & $1.419(4)$ & $\mathrm{C}(9)-\mathrm{C}(11)$ & $1.508(4)$ \\
$\mathrm{C}(12)-\mathrm{C}(13)$ & $1.446(5)$ & & \\
& & & \\
$\mathrm{N}(1)-\mathrm{Pd}(1)-\mathrm{N}(2)$ & $83.75(8)$ & $\mathrm{N}(4)-\mathrm{Pd}(1)-\mathrm{N}(1)$ & $96.21(9)$ \\
$\mathrm{N}(4)-\mathrm{Pd}(1)-\mathrm{N}(3)$ & $83.78(9)$ & $\mathrm{N}(4)-\mathrm{Pd}(1)-\mathrm{N}(2)$ & $177.61(9)$ \\
$\mathrm{N}(3)-\mathrm{Pd}(1)-\mathrm{N}(1)$ & $178.11(9)$ & $\mathrm{N}(3)-\mathrm{Pd}(1)-\mathrm{N}(2)$ & $96.19(9)$ \\
$\mathrm{C}(9)-\mathrm{N}(3)-\mathrm{C}(12)$ & $122.5(2)$ & $\mathrm{C}(7)-\mathrm{N}(2)-\mathrm{C}(2)$ & $127.3(2)$ \\
$\mathrm{C}(9)-\mathrm{N}(3)-\mathrm{Pd}(1)$ & $123.43(18)$ & $\mathrm{C}(7)-\mathrm{N}(2)-\mathrm{Pd}(1)$ & $120.62(17)$ \\
$\mathrm{C}(12)-\mathrm{N}(3)-\mathrm{Pd}(1)$ & $113.56(19)$ & $\mathrm{C}(2)-\mathrm{N}(2)-\mathrm{Pd}(1)$ & $111.49(15)$ \\
$\mathrm{N}(2)-\mathrm{C}(2)-\mathrm{C}(1)$ & $115.3(2)$ & $\mathrm{N}(2)-\mathrm{C}(7)-\mathrm{C}(8)$ & $123.3(2)$ \\
$\mathrm{N}(2)-\mathrm{C}(7)-\mathrm{C}(10)$ & $121.9(2)$ & $\mathrm{N}(3)-\mathrm{C}(9)-\mathrm{C}(8)$ & $122.4(2)$ \\
$\mathrm{C}(8)-\mathrm{C}(7)-\mathrm{C}(10)$ & $114.8(2)$ & $\mathrm{N}(3)-\mathrm{C}(9)-\mathrm{C}(11)$ & $120.8(2)$ \\
$\mathrm{C}(7)-\mathrm{C}(8)-\mathrm{C}(9)$ & $130.4(2)$ & $\mathrm{C}(12)-\mathrm{C}(13)-\mathrm{N}(4)$ & $113.7(2)$ \\
$\mathrm{C}(8)-\mathrm{C}(9)-\mathrm{C}(11)$ & $116.7(2)$ & & \\
\hline
\end{tabular}

meter equipped with a graphite crystal, incident-beam monochromator. Cell constants and orientation matrices for data collection were obtained from least-squares refinement, using the setting angles of 25 reflections. The data were collected for Lorentz-polarization and absorption corrections were applied to the data. The structure was solved by direct methods using SHELXS-86 and refined by full-matrix leastsquares calculations with SHELX-97. ${ }^{5 .}$ The final cycle of the refunement converged with $R=0.0218$ and $w R=0.0571$. Crystal data. details of the data collection. and refinement parameters were listed in Table 1. The selected bond distances and angles were presented in Table 2.

\section{Results and Discussion}

The UV-visible spectra of the free ligand $\mathbf{L}$ and the complex $[\mathbf{P d L}]$ newly prepared were illustrated in Figure $\mathbf{l}$. The spectrum of the $\mathbf{L}$ showed only one peak at $322 \mathrm{~nm}\left(\varepsilon_{\max }\right.$ $=36000 \mathrm{M}^{-1} \mathrm{~cm}^{-1}$ ) attributed to $\pi \rightarrow \pi^{4}$ transitions. while that of the [PdL] exhibited a band of ligand based at 374 $\left(\varepsilon_{m u x}=19000 \mathrm{M}^{-1} \mathrm{~cm}^{-1}\right)$ and a band at $432 \mathrm{~nm}\left(\varepsilon_{\max }=11000\right.$ $\left.\mathrm{M}^{-1} \mathrm{~cm}^{-1}\right)$ in $\mathrm{CHCl}_{3}$. The latter band may be attributed to ligand to metal charge transfer (LMCT) from the highest occupied ligand molecular orbital to the lowest empty $d-$ orbital of palladium. The LMCT band of the asymmetrical complex [PdL] shifted to higher energy than asymmetrical monobenzotetraazacyclo[14]annulene nickel(II) complex ( $\lambda_{\text {max }}=547 \mathrm{~nm}$ and $\varepsilon_{\text {max }}=3000 \mathrm{M}^{-1} \mathrm{~cm}^{-1}$ ) owing to the extended interaction by the larger $d$-orbital of palladium. ${ }^{13} \mathrm{Ln}$ the ${ }^{1} \mathrm{H}-\mathrm{NMR}$ dada. the characteristic peak $(\mathrm{N}-H)$ of freebased ligand appeared at 11.873 (s) ppm. while disappearing in the palladium(II) complex.

The cyclic voltammograms of the ligand $\mathrm{L}$ and the 


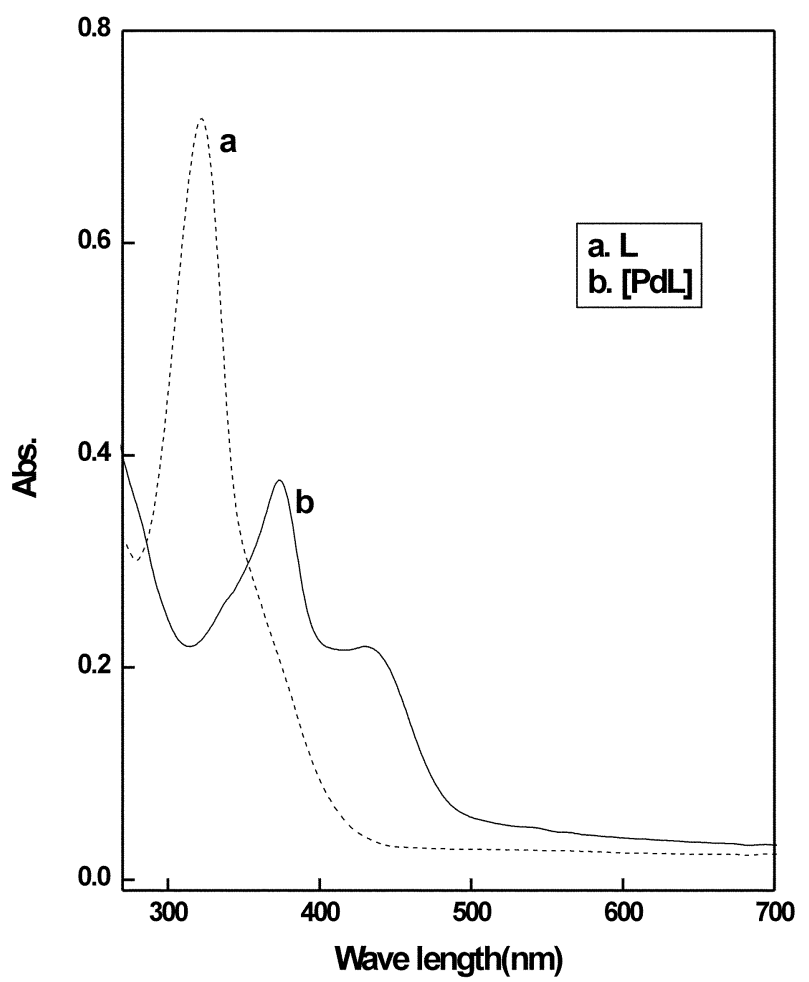

Figure 1. I:lectronic absorption spectra of free ligand and palladium(II) complex in chloroform solution at room temperature.

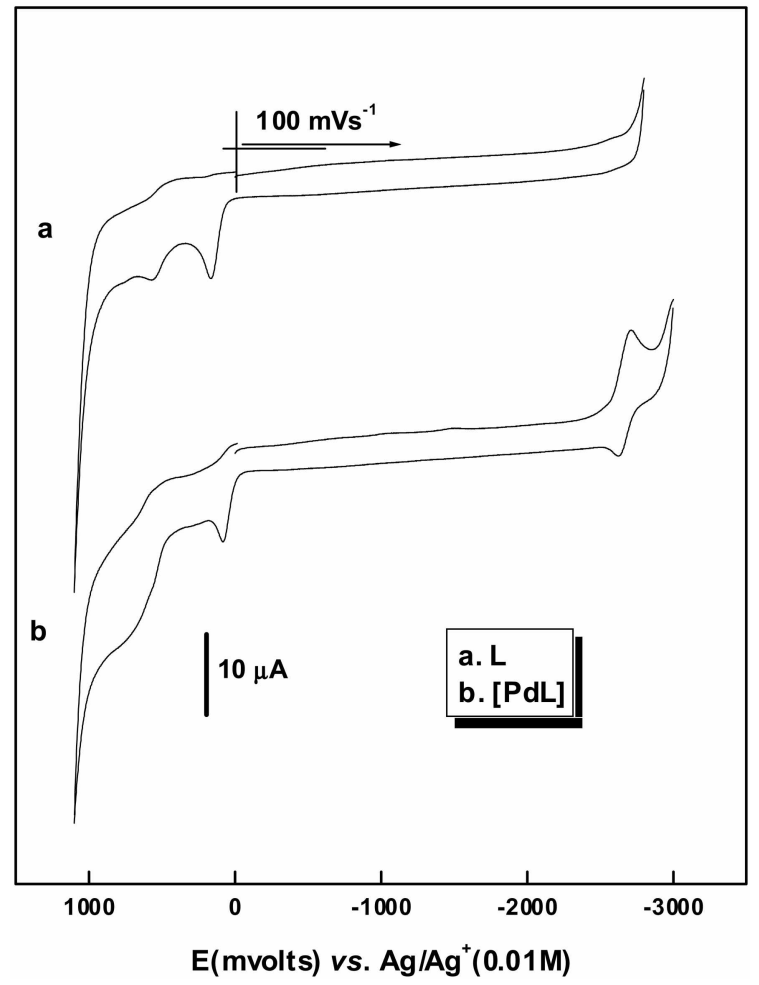

Figure 2. Cyclic voltammograms of free ligand and palladium(II) complex in a $0.1 \mathrm{MTL} \triangle \mathrm{P}-\mathrm{DMSO}$ solution at room temperature.

complex [PdL] measured in 0.1 M TEAP-DMSO solutions is $\mathrm{Ag} / \mathrm{Ag}(0.01 \mathrm{M})$ at $25^{\circ} \mathrm{C}$ and scan rates of $100 \mathrm{mVs}^{-1}$ were shown in Figure 2. The $\mathbf{L}$ has only two irreversible

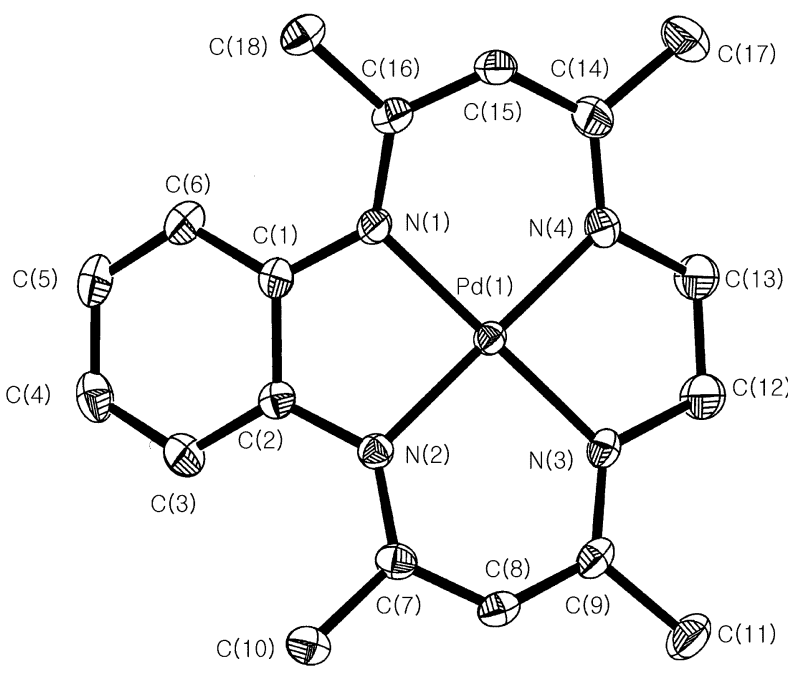

Figure 3. The molecular structure of palladiun(II) complex.

oxidation peaks at +0.170 and $-0.580 \mathrm{~V}$. The $|\mathbf{P d L}|$ has two irreversible oxidation peaks by one electron at +0.090 and $-0.700 \mathrm{~V}$, respectively, and one quasi-reversible reduction peak by one electron of palladium-based $\left(\mathrm{P}^{2+} \rightarrow \mathrm{Pd}^{+}\right)$at $-2.710 \mathrm{~V}$. Such assignments of redox waves are supported by similar observation with asymmetrical monobenzotetraazacyclo[14]annulene nickel(II) complex. ${ }^{27}$

The molecular structure of the complex $|\mathbf{P d L}|$ was drawn in Figure 3. Crystal data and refinement parameters and the selected bond distances and angles were presented in Tables 1 and 2, respectively. The average of four $\mathrm{Pd}-\mathrm{N}$ bond distances was $1.970 \AA$ that is longer than the corresponding $\mathrm{Ni}-\mathrm{N}$ distances ( $(1.870 \AA)$ for symınetrical nickel(II) complex ${ }^{28}$ but shorter than Pd-N distances (1.996 $\AA$ ) for symmetrical palladium complex ${ }^{18}$ owing to different basicity for phenylenediamine and ethylenediamine. Such difference of bond distances might be attributed to the larger ionic radius of palladium. Also, the distances of $\mathrm{N}-\mathrm{C}$ on the side of sixmembered rings were $1.343 \AA$ for $\mathrm{N}(1)-\mathrm{C}(16), 1.341 \AA$ for $\mathrm{N}(2)-\mathrm{C}(7), 1.307 \AA$ for $\mathrm{N}(3)-\mathrm{C}(9)$ and $1.391 \AA$ for $\mathrm{N}(4)-$ $\mathrm{C}(14)$, while for five-membered rings they were totally longer $(1.409 \AA$ for $\mathrm{N}(1)-\mathrm{C}(1), 1.410 \AA$ for $\mathrm{N}(2)-\mathrm{C}(2), 1.46 \mathrm{I}$ $\AA$ for $\mathrm{N}(3)-\mathrm{C}(12)$ and $1.452 \AA$ for $\mathrm{N}(4)-\mathrm{C}(13))$. The average $\mathrm{C}-\mathrm{C}$ distances in the six-membered chelate rings were 1.408 $\AA$ close to those of benzene $(1.40 \AA)$, reflecting some aromaticity that all $\pi$-electrons are somehow delocalized in the macrocycle ring. The average angles of N-Pd-N of five and six member rings were 83.76 and $96.20 \AA$, and N(3)-Pd$\mathrm{N}(1)$ and $N(4)-P d-N(2)$ were 178.11 and $177.61^{\circ}$, respectively, indicating the geometry close to a square planar a little bit distorted. The coordination environment around the central palladium(II) atom showed a square planar geometry with four $\mathrm{Pd}-\mathrm{N}$ bonds, which is very similar to that of symmetrical dibenzotetraazacyclo[14]annulene palladium(11) complex.

Supplementary material. Crystallographic data for the structural analysis have been deposited at the CCDC, 12 Union Road, Cambridge CB2 IEZ, UK on request, quoting the deposition number CCDC 222447. Copies of this 
information can be obtained free of charge via E-mail: depositaccdc.cam ac.uk or http://www.ccdc.cam.ac.uk: Tel: +44-1233-336031: Fax: +44-1223-336033.

Acknowledgement. This work was supported by Korea Research Foundation Grant (KRF-2002-C00012).

\section{References}

1. Hiller, H.: Dimroth. P; Pfitzner, H. Jushus Liebigs Amm. Chem. 1968, 717, 137

2. Goedken. V. L.: Park. Y. A. J. Chem. Soc. Chem. Commm. 1975. 214

3. Neves. D. R.: Dabrowiak. J. C. Inorg Chent. 1976. 15. 129

4. Weiss, M. C.: Bursten, B.: Peng. S. M.: Goedken, V. L. J. Amt. Chem. Soc. 1976. 98.8021.

5. Müller R. Wöhrle. D. Makromol. Chem. 1975. 176, 2775.

6. Bell. L. G.: Dabrowiak. J. C. J. Chem. Soc. Chem. Commm. 1975. 512 .

7. Gordon. G. C.: Dehaven. P. W.: Weiss. M. C.: Geedken. V. L. J. Am. Chem. Soc. 1978.100, 1003.

8. Beck, F.: Dammert, W.: Heiss. I. Miller, H: Polster, R. Z. Katufforsch. 1973, 28. 1009

9. Alt. H.: Binder. H.: Sandstede. G. J. Catal 1973. 28.8.

10. Beck. F. Ber: Bunsenges. Phvs. Chem. 1973. 77. 353.

11. Bailey. C. L.: Bereman. R. D.: Rillema. D. P. Inorg. Chem. 1986. 25,3149

12. Bailey C. L.: Bereman. R. D.: Rillema, D. P; Nowak. R. Inorg.
Chim. Acta 1986. 116, 245.

13. Hochgesang. P. T.: Bereman. R. D. Inorg. Chim. Acta 1989. 162. 191.

14. Hochgesang. P. T.: Bereman. R. D. Inorg Chim. Acta 1990. 167. 199

15. Thomas. D. W: Martell. A. E. J. Am. Chem. Soc. 1959. 81. 5111 .

16. Eisner. V: Harding. M. T. C. J. Chem Soc. 1964. 4089.

17. Goedken. V. L.: Pluth. I. J.: Peng. S. M.: Bursten. B. J. Am. Chen. Soc. 1976. 98.8014.

18. Tsutsui. M; Bobsein, R. L.: Cash. F.; Tettersen. R. Inorg. Chen 1979. 18,758

19. Park, Y. C.; Bae. Z. U.; Kim. S. S.; Baek. S. K. Bull. Kowan Chem. Soc. 1995. 16. 287.

20. Bae. Z. U.: Park. Y. C.: Lee. T. H.: Chang. H. Y.: Lee. S. H. Bull. Korean Chem. Soc. 2000.21 .749$.

21. Kolthoff, I. M.: Coetzee, J. F. J. Ant. Chem. Soc. 1957. 79. 1852 .

22. LEplattenier, F. A.: Pugin. A. Helv Chm Acta 1975, $58,917$.

23. Park. Y. C.: Kim. S. S.: Na. H. G.: Noh. Y. I. J. Coord. Chem. 1997. H. 191

24. Park. Y. C.: Kinn. S. S.: Lee. D. C.: An. C. H. Polvhedhon 1997. 16. 253 .

25. Sheldrick, G. M. Acta Coystallogr. Sect A 1990, 46. 467.

26. Sheldrick, G. M. SHEL 1-97; University of Göttingen: Göttinggen. Germany. 1997.

27. Park. Y. C.: Byut. T. C.: Choi. J. H.: Limn. T. W.: Lee. D. C.: Na. H. G. Polnhedron 2002. 21.923.

28. Weiss, M. C.: Gordon, G.: Goedken. V. L. Inorg Chen. 1977. 16. 305 . 